\title{
Combined effects of atorvastatin and aspirin on growth and apoptosis in human prostate cancer cells
}

\author{
YAN HE $^{1}$, HUARONG HUANG $^{1}$, CHELSEA FARISCHON $^{2}$, DONGLI LI $^{3}$, \\ ZHIYUN DU ${ }^{1}$, KUN ZHANG ${ }^{1,3}, \mathrm{XI}_{\text {ZHENG }}^{1,2,4}$ and SUSAN GOODIN ${ }^{4}$

\begin{abstract}
${ }^{1}$ Allan H. Conney Laboratory for Anticancer Research, Guangdong University of Technology, Guangzhou, Guangdong 510006, P.R. China; ${ }^{2}$ Department of Chemical Biology, Ernest Mario School of Pharmacy, Rutgers, The State University of New Jersey, Piscataway, NJ 08854, USA; ${ }^{3}$ Department of Chemical and Environmental Engineering, Wuyi University, Jiangmen, Guangdong 529020, P.R. China;

${ }^{4}$ Rutgers Cancer Institute of New Jersey, New Brunswick, NJ 08903, USA
\end{abstract}

Received July 22, 2016; Accepted November 30, 2016

DOI: $10.3892 /$ or.2017.5353

\begin{abstract}
Epidemiologic studies indicate the use of either statins or aspirin have beneficial effects in prostate cancer patients. The present study was undertaken to evaluate the effects and mechanisms of atorvastatin and aspirin alone or in combination in human prostate cancer cells cultured in vitro and grown as xenograft tumors in severe combined immune-deficient (SCID) mice. The growth and apoptosis in prostate cancer cells were determined by the trypan blue exclusion and propidium iodide staining assays. Activation of the nuclear factor $\kappa \mathrm{B}(\mathrm{NF}-\kappa \mathrm{B})$ was measured by luciferase reporter assay, and the levels of phospho-signal transducer and activator of transcription (Stat)3 and phospho-extracellular signal-regulated kinase (Erk)1/2 were determined by western blot analysis. Mice were injected subcutaneously with PC-3 cells in Matrigel. After 4-6 weeks, mice with PC-3 tumors received i.p. injections of vehicle, atorvastatin $(5 \mathrm{mg} / \mathrm{kg})$, aspirin $(80 \mathrm{mg} / \mathrm{kg})$, or atorvastatin $(5 \mathrm{mg} / \mathrm{kg})+$ aspirin $(80 \mathrm{mg} /$ $\mathrm{kg}$ ) three times a week for 30 days. Our results demonstrated the combination of atorvastatin and aspirin had more potent effects on growth inhibition and apoptosis stimulation in prostate cancer cells than either drug alone. Mechanistic studies indicated the induction of apoptosis in PC-3 cells was associated with strong inhibition of $\mathrm{NF}-\kappa \mathrm{B}$ and decreases in the levels of phospho-Stat 3 and phospho-Erk1/2. Results of the present study demonstrated a strong combined effect of atorvastatin and aspirin on inhibiting the growth of prostate
\end{abstract}

Correspondence to: Dr Susan Goodin, Rutgers Cancer Institute of New Jersey, 195 Little Albany St., New Brunswick, NJ 08903, USA E-mail: goodin@cinj.rutgers.edu

Dr Xi Zheng, Department of Chemical Biology, Ernest Mario School of Pharmacy, Rutgers, The State University of New Jersey, 164 Frelinghuysen Road, Piscataway, NJ 08854, USA

E-mail: xizheng@pharmacy.rutgers.edu

Key words: prostate cancer, atorvastatin, aspirin, apoptosis, $\mathrm{NF}-\kappa \mathrm{B}$ cancer cells in vitro and in vivo. The findings provide a strong rationale for clinical evaluation of the combination of atorvastatin and aspirin in patients with prostate cancer.

\section{Introduction}

Prostate cancer is the most frequently occurring cancer and second leading cause of cancer-related deaths in men (1). Although the five-year relative survival rate has increased over the past 25 years, prostate cancer is still the leading cause of cancer death in older men (1). While delaying the development of castrate resistant disease with the combination of hormonal therapy and chemotherapy has been shown to significantly improve overall survival (2), novel and less toxic approaches for delaying the progression of prostate cancer to castration independence would be of great benefit for patients.

Atorvastatin and other statins inhibit 3-hydroxy-3-methylglutaryl-CoA (HMG-CoA) reductase and are used clinically as an effective treatment for the control of hypercholesterolemia (3). Although earlier epidemiological studies on statin use and overall prostate cancer risk was not conclusive, large epidemiological studies observed that statin use was associated with a reduced risk of advanced prostate cancer (4-7). In addition, clinical study found that statin use was associated with a reduction in the risk of biochemical recurrence (8). Many studies indicate that COX-2 is overexpressed in human prostate adenocarcinoma (9-12) with consistently high levels observed in lymph node metastasis, suggesting that in the prostate, COX-2 may act early in tumor promotion and progression and potentially a target for drug therapy in the management of the disease. Earlier studies from our laboratory indicate that atorvastatin and celecoxib in combination synergistically inhibited the growth and induced apoptosis in cultured prostate cancer cells. This combination inhibited the progression of androgen-dependent LNCaP tumors to androgen independence and the growth of androgen-independent $\mathrm{PC}-3$ prostate tumors in SCID mice more effectively than either agent alone $(13,14)$. Clinically, however, cardiac toxicity is a concern for celecoxib with long-term use increasing the risk of cardiovascular events (15). Therefore, investigation of other non-steroidal 
anti-inflammatory drugs (NSAIDs) inhibiting COX-2 to use in combination with atorvastatin to inhibit prostate cancer growth is appropriate.

Aspirin is one of the most commonly used NSAIDs and has shown activity in a variety of cancers, including prostate cancer (16-18). Although results from several epidemiological studies for the association of aspirin use and prostate cancer were controversial (19-21), a recent meta-analysis of prospective and case-control cohort studies including over 100,000 prostate cancer cases worldwide found that aspirin was associated with a reduced risk of total prostate cancer and prostate cancer-specific mortality (22). In addition, in men with nonmetastatic prostate cancer, post-diagnosis daily aspirin use has been associated with lower prostate cancer-specific mortality among men diagnosed with high-risk prostate cancer $(\geq \mathrm{T} 3$ and/or Gleason score $\geq 8)(23-25)$. Since aspirin has inhibitory effect on COX-2 and anti-prostate cancer activities, we hypothesize that a combination of aspirin with atorvastatin will strongly inhibit the growth of prostate cancer.

In the present study, we evaluated the effects of atorvastatin alone or in combination with aspirin on the growth and apoptosis in $\mathrm{LNCaP}, \mathrm{VCaP}$ and PC-3 cells. Additionally, we evaluated the effect of these drugs alone or in combination on the growth of prostate xenograft tumors in SCID mice. We found that the combination of atorvastatin and aspirin strongly inhibited the growth of PC-3 tumors and the combination strongly induced apoptosis. We also found that the effects of the drug combination on proliferation and apoptosis were associated with inhibition of NF- $\mathrm{BB}$ and Stat 3 . These data provide a rationale for clinically evaluating the combined use of atorvastatin and aspirin in the treatment of prostate cancer.

\section{Materials and methods}

Cell culture and reagents. $\mathrm{LNCaP}, \mathrm{VCaP}$ and $\mathrm{PC}-3$ cells were obtained from the American Type Culture Collection (ATCC, Rockville, MD, USA). Aspirin, atorvastatin, propylene glycol, polysorbate 80 , benzyl alcohol, ethanol and DMSO were from Sigma (St. Louis, MO, USA). Matrigel was obtained from BD Biosciences (Bedford, MA, USA). RPMI-1640 tissue culture medium, penicillin-streptomycin, L-glutamine and fetal bovine serum (FBS) were from Gibco (Grand Island, NY, USA). The cells were maintained in RPMI-1640 culture medium containing $10 \%$ FBS that was supplemented with penicillin $(100 \mathrm{U} / \mathrm{ml})$-streptomycin $(100 \mu \mathrm{g} / \mathrm{ml})$ and L-glutamine $(300 \mu \mathrm{g} / \mathrm{ml})$. Cultured cells were grown at $37^{\circ} \mathrm{C}$ in a humidified atmosphere of $5 \% \mathrm{CO}_{2}$ and were passaged twice a week.

Determination of the number of viable cells. The inhibitory effect of atorvastatin and aspirin alone or in combination on human prostate cancer cells was determined using the trypan blue exclusion assay. In dose-dependent experiments, human prostate cancer $\mathrm{LNCaP}, \mathrm{VCaP}$ (both are androgen-dependent) and PC-3 (androgen-independent) cells were treated with different concentrations of atorvastatin or aspirin for $72 \mathrm{~h}$. The number of viable cells after each treatment was determined using a hemacytometer under a light microscope (Optiphot-2, Nikon, Tokyo, Japan). Cell viability was determined by the trypan blue exclusion assay, which was done by mixing $80 \mu \mathrm{l}$ of cell suspension and $20 \mu \mathrm{l}$ of $0.4 \%$ trypan blue solution for 2 min. Blue cells were counted as dead cells and the cells that did not absorb dye were counted as live cells.

Assessment of apoptotic cells. Apoptosis was determined by morphological assessment in cells stained with propidium iodide (PI) (26). Apoptotic cells were identified by classical morphological features including nuclear condensation, cell shrinkage, and formation of apoptotic bodies (26). Apoptosis was also determined by caspase-3 immunostaining with an antibody that reacts with the active form of caspase-3 (AF835, R\&D Systems, Minneapolis, MN, USA). In brief, cytospin slides were incubated with caspase-3 antibody for $30 \mathrm{~min}$ followed by incubation with a biotinylated anti-rabbit secondary antibody for $30 \mathrm{~min}$ and incubation with conjugated-avidin solution (ABC Elite ${ }^{\circledR}$ kit, Vector Laboratories, Burlingame, CA, USA) for $30 \mathrm{~min}$. Color development was achieved by incubation with $0.02 \%$ 3,3'-diaminobenzidin tetrahydrochloride containing $0.02 \%$ hydrogen peroxide for $10 \mathrm{~min}$ at room temperature.

Western blotting. The levels of phospho-Erk1/2 and phosphoStat 3 were determined by western blot analysis. PC-3 cells were seeded at a density of $1 \times 10^{5}$ cells $/ \mathrm{ml}$ of RPMI medium and incubated for $24 \mathrm{~h}$. The cells were then treated with atorvastatin $(5 \mathrm{mM})$ and aspirin $(0.5 \mathrm{mM})$ alone or in combination for $24 \mathrm{~h}$. After treatment, the cell lysates were prepared as described earlier (27). Proteins were subjected to sodium dodecyl sulfate polyacrylamide gel electrophoresis (SDS-PAGE) and transferred to nitrocellulose membrane. After blocking nonspecific binding sites with blocking buffer, the membrane was incubated overnight at $4^{\circ} \mathrm{C}$ with primary antibodies (\#9131 for phospho-Stat3 and \#9101 for phosphoErk1/2, both from Cell Signaling Co., Beverly, MA, USA). The $\beta$-actin detected by anti- $\beta$-actin antibody (sc- 47778 , Santa Cruz Biotechnology Inc., Dallas, TX, USA) was used as a loading control. Following removal of the primary antibody, the membrane was washed three times with TBS (PBS containing $0.05 \%$ Tween-20) buffer at room temperature and then incubated with fluorochrome-conjugated secondary antibody (925-32211, LI-COR Biotechnology, Lincoln, NE, USA). The membrane was then washed with TBS three times. Final detection was done with an Odyssey infrared imaging system (Li-Cor Biotechnology). The extent of protein loading was determined by blotting for $\beta$-actin, and the levels of phosphoErk1/2 and phospho-Stat 3 in the western blot was analyzed by optical density measurement and normalized for actin.

$N F-\kappa B$-dependent reporter gene expression assay. $\mathrm{NF}-\kappa \mathrm{B}$ transcriptional activity was measured by the NF- $\kappa \mathrm{B}$-luciferase reporter gene expression assay using the PC-3/N cells (28). This cell line was previously established in our laboratory by stable transfection of PC-3 cells with an NF- $\kappa \mathrm{B}$ luciferase construct (\#CLS-013L; SABiosciences, Valencia, CA, USA). A single stable clone, $\mathrm{PC}-3 / \mathrm{N}$ was obtained and used in the present study. In brief, $\mathrm{PC}-3 / \mathrm{N}$ cells were treated with aspirin or atorvastatin alone or in combination for $24 \mathrm{~h}$, and the $\mathrm{NF}-\kappa \mathrm{B}$-luciferase activities were measured using the luciferase assay kits from Promega (Madison, WI, USA). After 

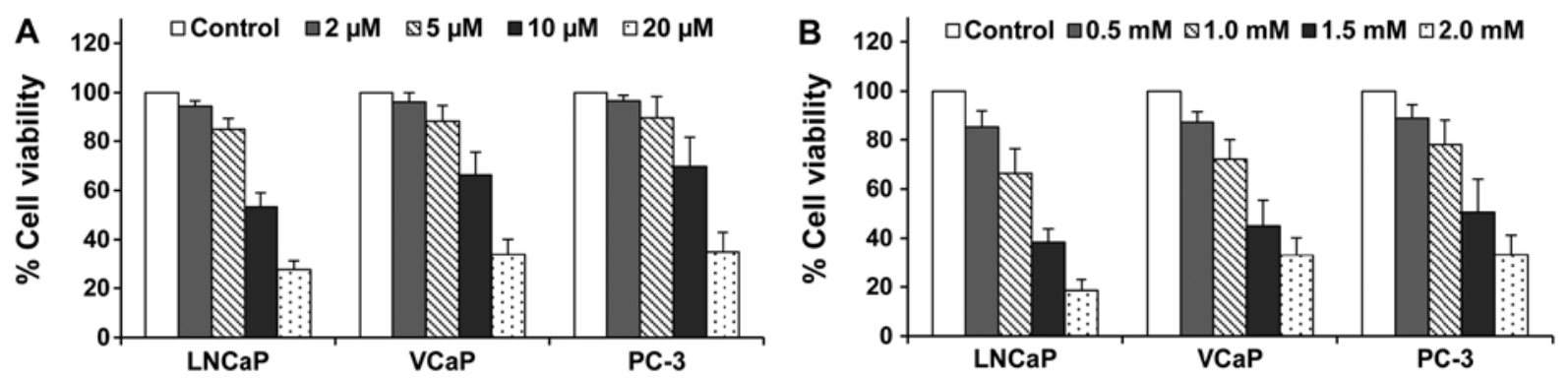

Figure 1. Effects of atorvastatin and aspirin on the growth of cultured prostate cancer cells. Human prostate cancer cells (LNCaP, VCaP and PC-3) were seeded at a density of $0.2 \times 10^{5}$ cells $/ \mathrm{ml}$ of medium in $35-\mathrm{mm}$ tissue culture dishes and incubated for $24 \mathrm{~h}$. The cells were then treated with various concentrations of atorvastatin or aspirin for $72 \mathrm{~h}$. Viable and dead cells were determined by the trypan blue exclusion assay. (A) Percent cell viability in the various cell lines treated with atorvastatin. (B) Percent cell viability in the various cell lines treated with aspirin. Each value represents mean \pm SE from three separate experiments.

treatments the cells were washed with ice-cold phosphate buffered-saline (PBS) and harvested in $1 \mathrm{X}$ reporter lysis buffer. After centrifugation, $10 \mu$ l aliquots of the supernatants were measured for luciferase activity by using a Luminometer from Turner Designs Instrument (Sunnyvale, CA, USA). The luciferase activity was normalized against known protein concentrations and expressed as percent of luciferase activity in the control cells, which were treated with DMSO solvent. The protein level was determined by Bio-Rad protein assay kits (Bio-Rad, Hercules, CA, USA) according to the manufacturer's instructions.

Formation and growth of PC-3 tumors in immunodeficient mice. Male severe combined immunodeficient (SCID) mice (6-7 weeksold) wereobtained from TacoFarms Inc.(Germantown, NY, USA). The animals were housed in sterile filter-capped microisolator cages and provided with sterilized food and water. Prostate cancer PC-3 cells $\left(2 \times 10^{6}\right.$ cells $\left./ 0.1 \mathrm{ml} / \mathrm{mouse}\right)$ suspended in 50\% Matrigel (Collaborative Research, Bedford, MA, USA) in RPMI-1640 medium were injected subcutaneously into the right flank of the mice. After approximately 4 weeks, mice with established xenograft tumors were injected with vehicle, atorvastatin $(5 \mathrm{mg} / \mathrm{kg})$, aspirin $(80 \mathrm{mg} / \mathrm{kg})$, or atorvastatin $(5 \mathrm{mg} / \mathrm{kg})$ + aspirin $(80 \mathrm{mg} / \mathrm{kg})$ three times a week for 30 days. Each group had 9 mice and all animals received the same amount of vehicle ( $5 \mu \mathrm{l} / \mathrm{g}$ body weight) which consisted of propylene glycol, polysorbate 80 , benzyl alcohol, ethanol and water (40: 0.5: 1: 10: 48.5). Tumor size (length $\mathrm{x}$ width) and body weight were measured three times a week. At the end of the study, mice were sacrificed, tumors were excised, weighed and placed in phosphate-buffered formalin at room temperature for $48 \mathrm{~h}$ and then placed in ethanol for $48 \mathrm{~h}$ before preparing paraffin sections as previously described (29). All animal experiments were carried out under an Institutional Animal Care and Use Committee (IACUC)-approved protocol (RU02-001).

Assay of tumor cell proliferation. Proliferation of the PC-3 xenograft tumors was determined by measuring the expression of proliferating cell nuclear antigen (PCNA) using immunohistochemical staining. In brief, tumors were excised from each mouse and weighed at the end of the experiment. Tumor tissues were fixed in buffered formalin for $24 \mathrm{~h}$ and then with ethanol for $48 \mathrm{~h}$. Paraffin blocks of tumor tissues were prepared and paraffin sections of tumor tissues were processed for immunohistochemical staining. The sections were incubated with PCNA antibody (MAB424, Millipore Corp. Billerica, MA, USA) for $1 \mathrm{~h}$ at room temperature. The sections were then incubated with a biotinylated secondary antibody for 30 min followed by incubation with horseradish peroxidase conjugated-avidin solution for $30 \mathrm{~min}$ using the Elite ABC kit (PK-6100, Vector Laboratories). PCNA staining in tumor cells (brown color in nucleus) were examined under a microscope (Optiphot-2, Nikon). At least 1000 cells were counted for each section.

Statistical analyses. Statistical analyses were done by using InStat software (GraphPad Software, Inc., La Jolla, CA, USA). The analysis of variance (ANOVA) was used for the comparison of growth inhibition, apoptosis and NF- $\kappa \mathrm{B}$ in the in vitro studies, and for comparison of tumor size, body weight and PCNA positive cells in the in vivo studies.

\section{Results}

Effects of atorvastatin and aspirin on growth and apoptosis of human prostate cancer cells. Treatment of different prostate cancer cells with atorvastatin or aspirin inhibited the cell growth in a concentration-dependent manner. The inhibitory effect of atorvastatin or aspirin were similar among the three prostate cancer cell lines tested. Treatment of the cells with atorvastatin at $5 \mu \mathrm{M}$ alone or aspirin at $0.5 \mathrm{mM}$ alone resulted in $10-15 \%$ decrease in the number of viable cells (Fig. 1). As shown in Table I, the combination of atorvastatin and aspirin had a more potent effect for inhibiting the growth of $\mathrm{LNCaP}$, VCaP and PC-3 cells than either agent alone. Statistical analysis using ANOVA with the Tukey-Kramer multiple comparison test showed that the percentage of viable cells was significantly lower in the atorvastatin and aspirin combination-treated group than in the atorvastatin- or aspirin-treated groups.

Treatment of different prostate cancer cells with atorvastatin or aspirin resulted in a concentration-dependent increase in the number of apoptotic cells (Fig. 2). As determined by morphological assessment and caspase-3 staining, atorvastatin and aspirin in combination had more potent stimulatory effect on apoptosis in LNCaP, VCaP and PC-3 cells than with either agent alone. Statistical analysis using ANOVA with the TukeyKramer multiple comparison test showed that the percentage of apoptotic cells was significantly higher in the atorvastatin 

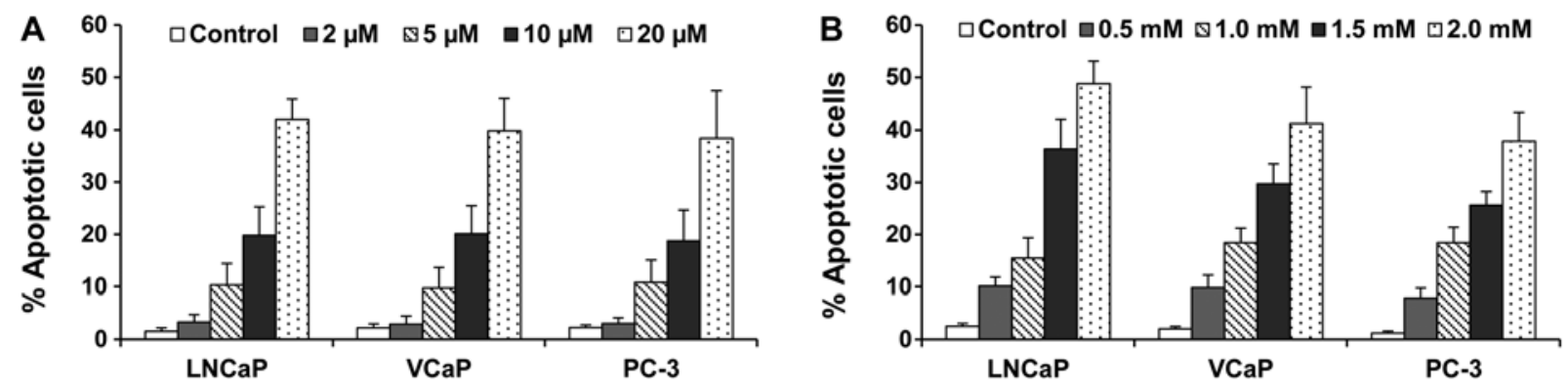

Figure 2. Effects of atorvastatin and aspirin on apoptosis of cultured prostate cancer cells. Human prostate cancer cells (LNCaP, VCaP and PC-3) were seeded at a density of $0.2 \times 10^{5}$ cells $/ \mathrm{ml}$ of medium in $35-\mathrm{mm}$ tissue culture dishes and incubated for $24 \mathrm{~h}$. The cells were then treated with various concentrations of atorvastatin or aspirin for $72 \mathrm{~h}$. Apoptotic cells were determined by propidium iodide staining and morphological assessment. (A) Percent apoptotic cells in different prostate cancer cell lines treated with atorvastatin. (B) Percent apoptotic cells in different prostate cancer cell lines treated with aspirin. Each value represents mean $\pm \mathrm{SE}$ from three separate experiments.

Table I. Effects of atorvastatin and aspirin alone or in combination on the growth and apoptosis in LNCaP, VCaP and PC-3 cells.

\begin{tabular}{|c|c|c|c|}
\hline \multirow[b]{2}{*}{ Treatment } & \multirow[b]{2}{*}{$\begin{array}{l}\text { Viable cells } \\
\text { (\% of control) }\end{array}$} & \multicolumn{2}{|c|}{ Apoptotic cells \% } \\
\hline & & $\begin{array}{l}\text { Morphological } \\
\text { assessment }\end{array}$ & $\begin{array}{c}\text { Caspase-3 } \\
\text { staining }\end{array}$ \\
\hline \multicolumn{4}{|l|}{ LNCaP cells } \\
\hline Control & 100 & $2.0 \pm 0.4$ & $1.8 \pm 0.3$ \\
\hline Atorvastatin $(5 \mu \mathrm{M})$ & $86.7 \pm 4.4$ & $9.3 \pm 1.1$ & $10.0 \pm 0.9$ \\
\hline Aspirin $(0.5 \mathrm{mM})$ & $87.0 \pm 4.8$ & $7.9 \pm 1.3$ & $8.4 \pm 1.0$ \\
\hline Atorvastatin $(5 \mu \mathrm{M})+\operatorname{aspirin}(0.5 \mathrm{mM})$ & $60.1 \pm 10.7^{\mathrm{a}}$ & $22.3 \pm 5.5^{\mathrm{a}}$ & $25.1 \pm 5.4^{\mathrm{a}}$ \\
\hline \multicolumn{4}{|l|}{ VCaP cells } \\
\hline Control & 100 & $1.7 \pm 0.5$ & $2.2 \pm 0.2$ \\
\hline Atorvastatin $(5 \mu \mathrm{M})$ & $90.3 \pm 2.7$ & $7.8 \pm 2.2$ & $8.8 \pm 1.0$ \\
\hline Aspirin $(0.5 \mathrm{mM})$ & $86.6 \pm 6.3$ & $10.3 \pm 1.8$ & $10.5 \pm 1.5$ \\
\hline Atorvastatin $(5 \mu \mathrm{M})+\operatorname{aspirin}(0.5 \mathrm{mM})$ & $63.4 \pm 8.2^{\mathrm{a}}$ & $24.3 \pm 7.1^{\mathrm{a}}$ & $26.0 \pm 6.4^{\mathrm{a}}$ \\
\hline \multicolumn{4}{|l|}{ PC -3 cells } \\
\hline Control & 100 & $1.1 \pm 0.5$ & $1.6 \pm 0.3$ \\
\hline Atorvastatin $(5 \mu \mathrm{M})$ & $91.5 \pm 4.5$ & $7.5 \pm 2.0$ & $9.0 \pm 1.1$ \\
\hline Aspirin $(0.5 \mathrm{mM})$ & $87.6 \pm 7.0$ & $8.2 \pm 2.0$ & $9.5 \pm 2.1$ \\
\hline Atorvastatin $(5 \mu \mathrm{M})+\operatorname{aspirin}(0.5 \mathrm{mM})$ & $53.0 \pm 8.9^{\mathrm{b}}$ & $29.6 \pm 8.1^{\mathrm{a}}$ & $31.6 \pm 8.4^{\mathrm{a}}$ \\
\hline
\end{tabular}

+ aspirin-treated group than in the atorvastatin- or aspirintreated groups $(p<0.01)$. Since the combination of atorvastatin and aspirin had stronger effects on growth inhibition and apoptosis induction in the PC-3 cells, we chose the PC-3 line for further in vitro and in vivo studies.

Inhibitory effect of atorvastatin and aspirin on $N F-\kappa B$ transcriptional activity. Treatment of $\mathrm{PC}-3 / \mathrm{N}$ cells with atorvastatin or aspirin dose-dependently decreased the luciferase activity in PC-3/N cells indicating an inhibition of the NF- $\mathrm{KB}$ activation (Fig. 3). The combination of atorvastatin and aspirin had a much stronger effect than either agent alone (Fig. 3). Statistical analysis using ANOVA with the Tukey-Kramer multiple comparison test showed significant differences for the luciferase activity between the atorvastatin-treated group and the combination-treated group $(\mathrm{p}<0.001)$, and between the aspirintreated group and the combination-treated group $(\mathrm{p}<0.01)$.

Effects of atorvastatin and aspirin on the level of phosphoStat 3 and phospho-Erk1/2. Treatment of PC-3 cells with atorvastatin $(5 \mu \mathrm{M})$ resulted in a moderate decrease in the level of phospho-Erk1/2 while aspirin $(0.5 \mathrm{mM})$ only had a 

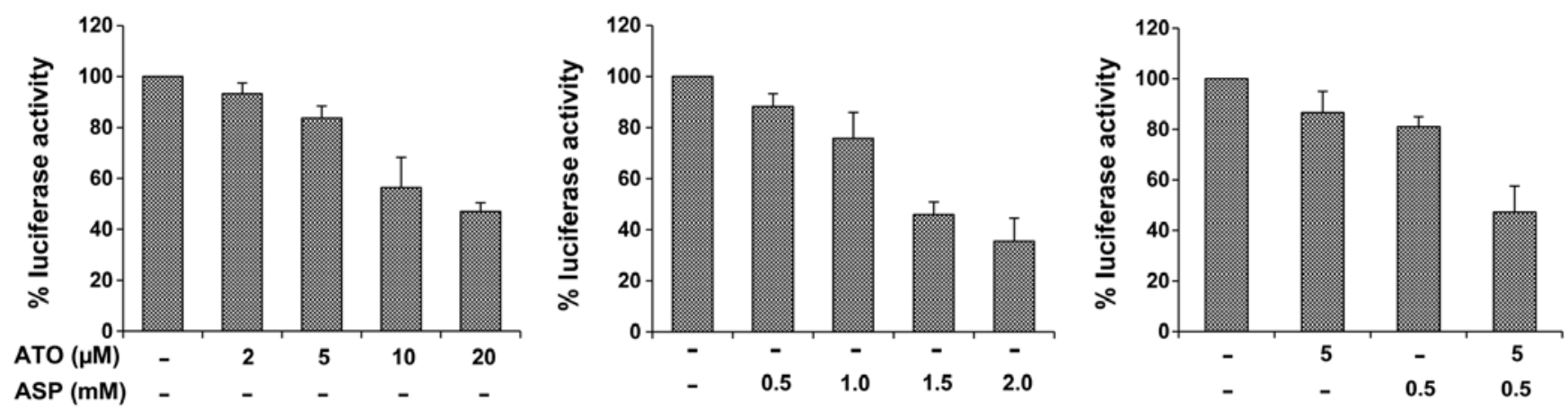

Figure 3. Effects of atorvastatin and aspirin on $\mathrm{NF}-\kappa \mathrm{B}$ transcriptional activity. PC-3/ $\mathrm{N}$ cells were seeded at a density of $0.2 \times 10^{5}$ cells/ml of medium in $12-\mathrm{well}$ plates and incubated for $24 \mathrm{~h}$. The cells were then treated with atorvastatin (ATO) alone or in combination with aspirin (ASP) for $24 \mathrm{~h}$. The NF- $\mathrm{B}$ transcriptional activity was measured by a luciferase activity assay and expressed as percentage relative to the control (100\%).

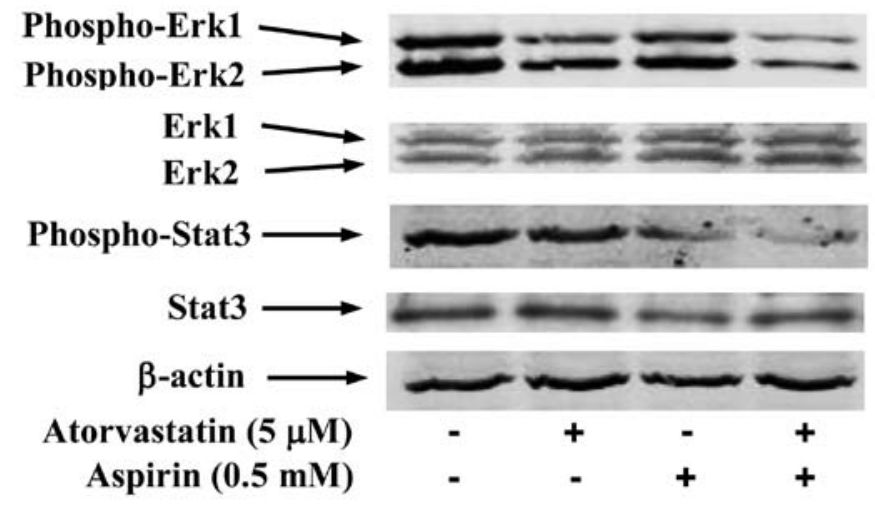

Figure 4. Effects of atorvastatin and aspirin on the levels of phospho-Erk1/2 and phospho-Stat 3 in PC-3 cells. PC-3 cells were seeded at a density of $1 \times 10^{5}$ cells $/ \mathrm{ml}$ of RPMI medium and incubated for $24 \mathrm{~h}$. The cells were then treated with atorvastatin $(5 \mathrm{mM})$ and aspirin $(0.5 \mathrm{mM})$ alone or in combination for $24 \mathrm{~h}$. The levels of phospho-Erk1/2 and phospho-Stat 3 were determined by western blot analysis.

small effect on decreasing the level of this protein (Fig. 4). The combination of atorvastatin $(5 \mu \mathrm{M})$ and aspirin $(0.5 \mathrm{mM})$ caused a stronger decrease in the level of phospho-Erk1/2 than either agent alone. The level of phospho-Erk1 relative to control (1.00) was 0.74 in cells treated with atorvastatin, 0.91 in cells treated with aspirin and 0.22 in cells treated with the combination of atorvastatin and aspirin. The level of Erk1 relative to control (1.00) was 0.97 in cells treated with atorvastatin, 1.05 in cells treated with aspirin and 1.06 in cells treated with the combination of the two drugs. The relative level of phospho-Erk 2 was 1.00 in control, 0.87 in cells treated with atorvastatin, 0.93 in cells treated with aspirin and 0.39 in cells treated with the combination of atorvastatin and aspirin. The level of Erk2 relative to control (1.00) was 1.02 in cells treated with atorvastatin, 1.05 in cells treated with aspirin and 1.07 in cells treated with the combination of the two drugs. As shown in Fig. 4, the drug combination also strongly decreased the level of phospho-Stat 3 in PC-3 cells. The level of phosphoStat 3 relative to control (1.00) was 0.97 in cells treated with atorvastatin, 0.55 in cells treated with aspirin and 0.12 in cells treated with the combination of atorvastatin and aspirin. The relative level of Stat 3 was 1.00 in control, 1.04 in cells treated with atorvastatin, 0.97 in cells treated with aspirin and 1.02 in cells treated with the combination of the two drugs.
In vivo effect of atorvastatin and aspirin on the growth of $P C-3$ tumors. Treatment with atorvastatin alone $(5 \mathrm{mg} / \mathrm{kg})$ resulted in a small inhibition on the growth of PC-3 tumors, while aspirin alone $(80 \mathrm{mg} / \mathrm{kg})$ had a moderate inhibitory effect. The combination of atorvastatin $(5 \mathrm{mg} / \mathrm{kg})$ and aspirin $(80 \mathrm{mg} / \mathrm{kg})$ had a potent effect on inhibiting the growth of PC-3 tumors (Fig. 5A). The mean \pm SE for percent initial tumor size at the end of the experiment was $248.3 \pm 18.3$ for the control group, $215.4 \pm 14.0$ for the atorvastatin-treated group, 192.3 \pm 9.9 for the aspirin-treated group, 140.8 \pm 8.1 for the animals treated with combination of atorvastatin and aspirin. Statistical analysis using ANOVA with the Tukey-Kramer multiple comparison test showed statistically significant differences in the average tumor size between the control group and the aspirin-treated group $(\mathrm{p}<0.05)$, and between the control group and the combination-treated group $(\mathrm{p}<0.001)$. The average tumor size in the combination-treated group was significantly smaller than that in the atorvastatin-treated group $(\mathrm{p}<0.01)$ and that in the aspirin-treated group $(\mathrm{p}<0.05)$.

Tumor weights in each animal in the different treatment groups at the end of the experiment is shown in Fig. 5B. The mean $\pm \mathrm{SE}$ for tumor weight $(\mathrm{g})$ was $0.74 \pm 0.06$ for the control group, $0.60 \pm 0.07$ for the atorvastatin-treated group, $0.53 \pm 0.04$ for the animals treated with aspirin, and $0.31 \pm 0.05$ for the animals treated with the drug combination. Statistical analysis using ANOVA with the Tukey-Kramer multiple comparison test showed that the average tumor weight in the combination group was significantly lower than that in the atorvastatin-treated group $(\mathrm{p}<0.01)$ and that in aspirin-treated group $(\mathrm{p}<0.05)$. We also determined the correlation between tumor size and tumor weight, and found a good correlation $(r=0.80)$ between these two measurements (Fig. 5C). Treatment with atorvastatin and aspirin alone or in combination did not affect the body weight of the mice (Fig. 5D). Statistical analysis using ANOVA with the TukeyKramer multiple comparison test showed that the differences in the percent of initial body weight between the control group and any of the treatment group were not statistically significant ( $\mathrm{p}>0.05)$ (Fig. 5Z).

Effect of atorvastatin and aspirin on the proliferation of $P C-3$ tumors. Immunohistochemical staining of PCNA in paraffin sections of PC-3 tumors showed that treatment of SCID mice with atorvastatin or aspirin alone resulted in a moderate 
A
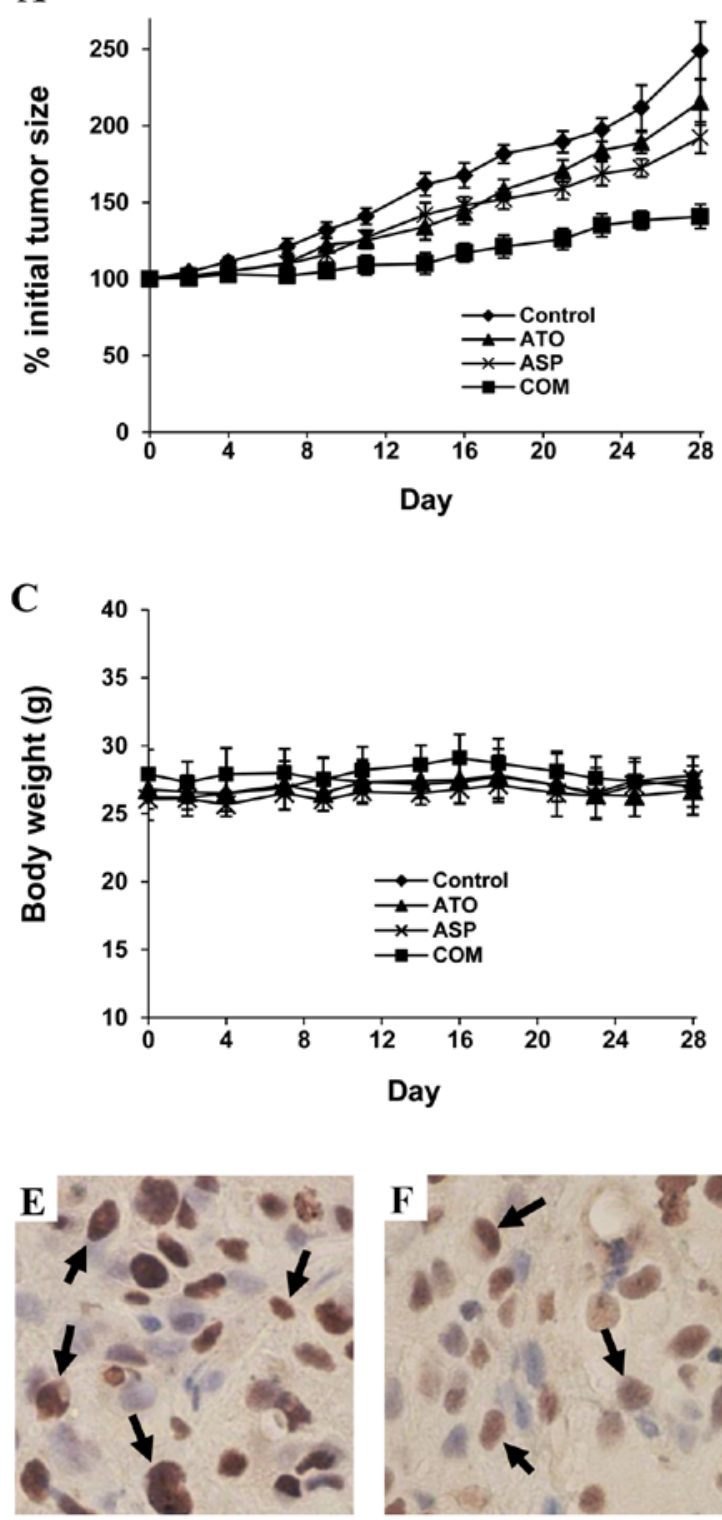

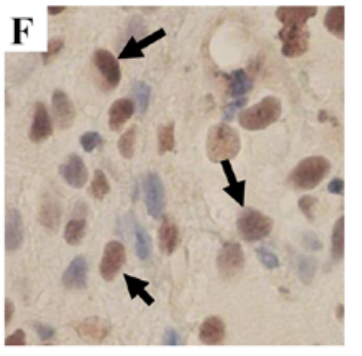

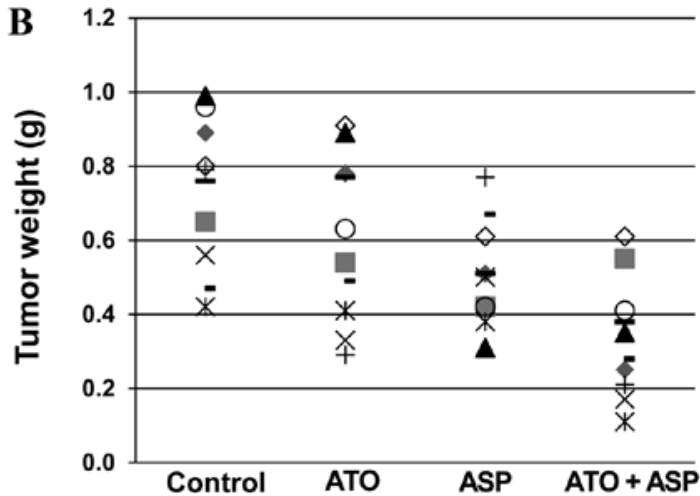
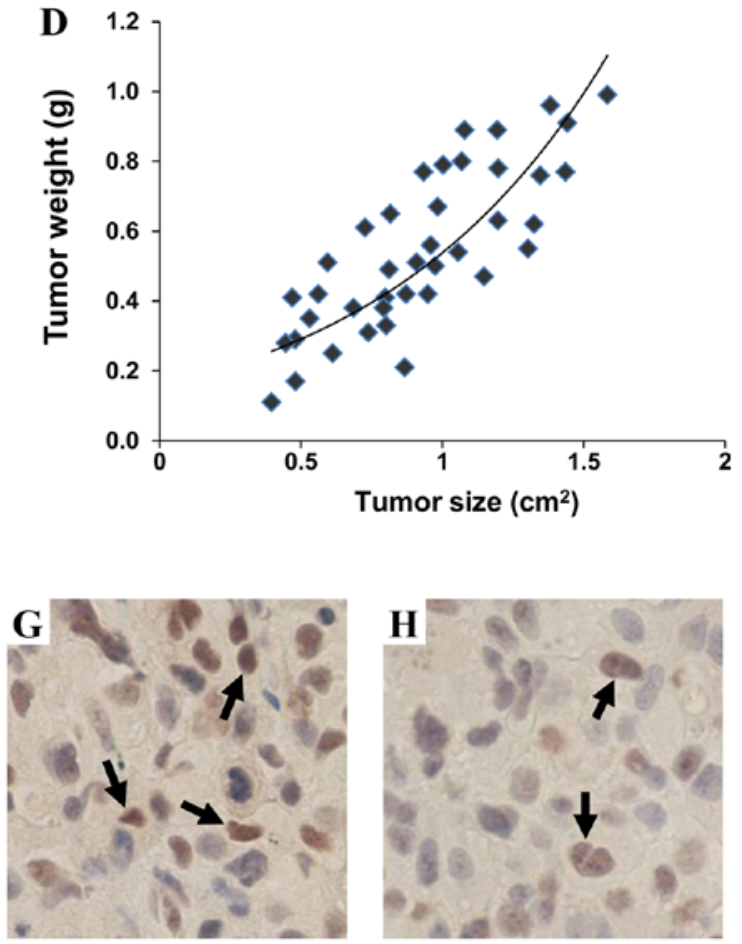

Figure 5. Effects of atorvastatin and aspirin on the growth of PC-3 xenograft tumors. Male SCID mice were injected subcutaneously with PC-3 cells ( $2 \times 10^{6}$ cells/mouse). Four weeks later, mice with established PC-3 tumors were randomly assigned to 4 groups. Mice in group 1 received i.p. injections with vehicle (propylene glycol, polysorbate 80, benzyl alcohol, ethanol and water with a ratio of 40: 0.5: 1: 10: 48.5). Mice in group 2 received i.p. injections with atorvastatin (ATO; $5 \mathrm{mg} / \mathrm{kg}$ ). Mice in group 3 received i.p. injection of aspirin (ASP; $80 \mathrm{mg} / \mathrm{kg}$ ), and mice in group 4 received i.p. injections with atorvastatin $(5 \mathrm{mg} / \mathrm{kg})+$ aspirin $(80 \mathrm{mg} / \mathrm{kg})$. Tumor size (length $\mathrm{x}$ width) and body weight were measured three times a week and expressed as percentage of initial tumor size and body weight. PCNA expression was done by immunohistochemical staining in paraffin sections of PC-3 tumors. (A) Percentage of initial tumor size. (B) The weight ( $\mathrm{g}$ ) of each tumor was measured at the end of the experiment in mice after sacrifice. (C) Body weight was expressed as percentage of initial body weight. (D) Correlation of tumor size $\left(\mathrm{cm}^{2}\right)$ and tumor weight (g). Representative micrographs of PCNA staining in PC-3 tumors from the control group (E), the atorvastatin-treated group $(\mathrm{F})$, the aspirin-treated group $(\mathrm{G})$ and the combination-treated group $(\mathrm{H})$ are shown. PCNA positive staining shows brown color in the nucleus.

decrease in the number of PCNA positive cells (Fig. $5 \mathrm{~F}$ and $\mathrm{G}$ ). Treatment of the mice with the combination of atorvastatin and aspirin resulted a potent decrease in the number of PCNA positive cells (Fig. $5 \mathrm{H}$ ). The mean \pm SD of percent PCNA positive cells was $70.3 \pm 8.5$ in tumors from the control group, $60.3 \pm 6.6$ in tumors from the atorvastatin-treated group, 54.9 \pm 7.5 in tumors from the aspirin-treated group and $41.9 \pm 5.1$ in tumors from the combination-treated group. The differences in the number of PCNA positive cells were statistically significant between the combination-treated group and the atorvastatintreated group $(\mathrm{p}<0.001)$, and between the combination-treated group and the aspirin-treated group $(\mathrm{p}<0.01)$.

\section{Discussion}

Recent large-scale epidemiological studies and a meta-analysis have shown that aspirin use was associated with reduced risk of overall and advanced prostate cancer risk $(22,30)$. In addition, post-diagnosis use of aspirin was associated with lower prostate cancer specific mortality in patients with high-risk disease (23-25). Use of the cholesterol lowering statins has also been shown to have protective effects on prostate cancer including decreased aggressiveness and significant decreases in both all-cause and prostate cancer specific mortality (4-8). In the present study, we demonstrated that atorvastatin in 
combination with aspirin strongly inhibited the growth and induced apoptosis in prostate cancer cells. Our study provided the first evidence that the atorvastatin combined with aspirin had in vivo anti-prostate cancer activity. The drug combination strongly inhibited the growth of prostate xenograft tumors in SCID mice. Our results, coupled with the epidemiologic evidence with each agent alone, provide a strong rationale for clinically evaluating the combination of atorvastatin and aspirin in prostate cancer patients.

Multiple mechanisms for the growth inhibitory effects of aspirin in prostate tumorigenesis have been suggested. Aspirin is a noncompetitive inhibitor of the COX-enzymes 1 and $2(16,31)$. COX-2 has an important role in tumor angiogenesis and overexpression of this enzyme was found in prostate cancer $(9-12,32)$. COX also produces ligands for peroxisome proliferator-activated receptor gamma (PPAR- $\gamma$ ), a modulator of proliferation and apoptosis in many cancer cell types (33). In the present study, we found that aspirin inhibited activation of NF- $\mathrm{NB}$ as determined by the luciferase reporter assay. Aspirin also decreased the level of phospho-Stat3. Our results suggest that aspirin inhibits multiple pathways in prostate cancer PC-3 cells.

The statin family of drugs inhibits 3-hydroxy-3-methylglutaryl-CoA (HMG-CoA) reductase and is used clinically as a safe and effective approach for the control of hypercholesterolemia (34). Earlier studies have indicated that in addition to the cholesterol-lowering effect, statins have pleotropic activities that modulate other biologic processes, such as cell proliferation and apoptosis by inhibiting $N F-\kappa B$ and Erk1/2 (35). HMG-CoA reductase produces farnesylpyrophosphate (FPP) and geranylgeranylpyrophosphate (GGPP) (36). FPP and GGPP are involved in the activation of Ras which is important for regulating cell growth and apoptosis (37). Results of the present study showed that atorvastatin decreased the level of Erk which is a downstream target of the Ras pathway (37).

The mechanisms by which atorvastatin and aspirin in combination strongly inhibited the growth and induced apoptosis in prostate cancer cells are not clear. We found the combination of atorvastatin and aspirin had more potent inhibitory effect on activation of the transcription factor $N F-\kappa B$ than either drug used alone. Strong inhibition of $\mathrm{NF}-\kappa \mathrm{B}$ activity by the drug combination may lead to a strong down regulation of its anti-apoptotic genes and contributed to the combined effect of atorvastatin and aspirin. Atorvastatin alone had a moderate effect on inhibition of Erk1/2 and aspirin alone only caused small decrease in phosphor-Erk $1 / 2$ while the combination of these two drugs strongly decreased the level of phosphor-Erk1/2. In addition, we found that the combination more potently inhibited Stat 3 than either drug alone. Our unpublished preliminary study indicated that atorvastatin and aspirin in combination inhibited androgen receptor (AR) activity as measured by the luciferase reporter assay. However, the strong combined effect of atorvastatin and aspirin on androgen-independent PC-3 cells showed in our current study indicates that AR-independent mechanisms were involved. The results of the mechanistic studies described above indicate that the combination of atorvastatin and aspirin target multiple signaling pathways important in regulation of prostate cancer cell growth and survival. Simultaneously inhibition of these important pathways may lead to a strong inhibition in the growth and strong induction of apoptosis in prostate cancer cells.

A recent retrospective case-control study in Mediterranean men undergoing a prostate biopsy reported the use of the combination of aspirin and statins resulted in significantly less men diagnosed with prostate cancer compared to the untreated group $(\mathrm{p}<0001)(38)$. The investigators also evaluated the in vitro effects of aspirin, simvastatin and the combination in LNCaP and PC3 cells. The combination of aspirin and simvastatin significantly reduced proliferation in both LNCaP and PC-3 cells compared to the untreated control with no comparison to either drug alone (38). The in vivo effect of the drug combination was not investigated in this study. In our present study, we evaluated the effects of aspirin and atorvastatin alone or in combination on growth inhibition and apoptosis in cultured LNCaP, VCaP and PC-3 cells, and in PC-3 xenograft tumors in SCID mice. In addition to the strong combined effect of aspirin and atorvastatin on growth inhibition and apoptosis in cultured prostate cancer cells, we showed that treatment of SCID mice with atorvastatin and aspirin in combination more potently inhibited the growth of PC-3 tumors than either drug along.

In the in vivo study, SCID mice bearing PC-3 xenograft tumors were treated with aspirin and atorvastatin alone or in combination. The dose $5 \mathrm{mg} / \mathrm{kg}$ for atorvastatin and $80 \mathrm{mg} / \mathrm{kg}$ for aspirin used in the present study was chosen based on the effective doses of atorvastatin and aspirin in our previous studies and other publications $(13,14,39)$. Atorvastatin or aspirin alone only had a moderate inhibitory effect on the growth of PC-3 tumors. The combination of the two drugs more potently inhibited the growth of PC-3 tumors than either drug used alone. Treatment of SCID mice with i.p. injections of atorvastatin (5 mg/kg body weight) and aspirin $(80 \mathrm{mg} / \mathrm{kg}$ body weight) alone or in combination did not cause body weight loss in the animals. In addition, no abnormalities were found in the major organs at the end of the experiment indicating that atorvastatin and aspirin at the doses used in the present study were not toxic to the animals.

In summary, we demonstrated in our current study that the combination of atorvastatin with aspirin at therapeutic concentrations potently inhibited the growth and stimulated apoptosis in human prostate cancer cells. Strong effects of atorvastatin and aspirin on growth inhibition and apoptosis induction in prostate cancer cells were associated with inhibition of $\mathrm{NF}-\kappa \mathrm{B}$ activation, decreased levels of phospho-Stat 3 and phosphoErk1/2. Moreover, treatment of SCID mice with a combination of atorvastatin and aspirin strongly inhibited the growth of xenograft PC-3 tumors. The combination of atorvastatin and aspirin may be an effective approach for delaying the progression of prostate cancer and should be evaluated clinically.

\section{Acknowledgements}

The present study was supported by the Guangdong Province Leadership Grant, China National Science Foundation Grants (grant no. 81272452 and 21272043), and the Rutgers Cancer Institute of New Jersey (CCSG P30-CA072720). The authors dedicate this study to Dr Allan H. Conney, an outstanding and widely recognized cancer researcher who passed away on September 10, 2013. 


\section{References}

1. Siegel RL, Miller KD and Jemal A: Cancer statistics, 2016. CA Cancer J Clin 66: 7-30, 2016.

2. Sweeney CJ, Chen YH, Carducci M, Liu G, Jarrard DF, Eisenberger M, Wong YN, Hahn N, Kohli M, Cooney MM, et al: Chemohormonal therapy in metastatic hormone-sensitive prostate cancer. N Engl J Med 373: 737-746, 2015

3. Malhotra HS and Goa KL: Atorvastatin: An updated review of its pharmacological properties and use in dyslipidaemia. Drugs 61: 1835-1881,2001.

4. Jacobs EJ, Rodriguez C, Bain EB, Wang Y, Thun MJ and Calle EE: Cholesterol-lowering drugs and advanced prostate cancer incidence in a large U.S. cohort. Cancer Epidemiol Biomarkers Prev 16: 2213-2217, 2007.

5. Flick ED, Habel LA, Chan KA, Van Den Eeden SK, Quinn VP, Haque R, Orav EJ, Seeger JD, Sadler MC, Quesenberry CP Jr, et al: Statin use and risk of prostate cancer in the California Men's Health Study cohort. Cancer Epidemiol Biomarkers Prey 16: 2218-2225, 2007.

6. Murtola TJ, Tammela TL, Lahtela J and Auvinen A: Cholesterollowering drugs and prostate cancer risk: A population-based case-control study. Cancer Epidemiol Biomarkers Prev 16 : 2226-2232, 2007.

7. Platz EA, Leitzmann MF, Visvanathan K, Rimm EB, Stampfer MJ, Willett WC and Giovannucci E: Statin drugs and risk of advanced prostate cancer. J Natl Cancer Inst 98: 1819-1825, 2006

8. Cyrus-David MS, Weinberg A, Thompson T and Kadmon D: The effect of statins on serum prostate specific antigen levels in a cohort of airline pilots: A preliminary report. J Urol 173: 1923-1925, 2005.

9. Anai S, Tanaka M, Shiverick KT, Kim W, Takada S, Boehlein S, Goodison S, Mizokami A and Rosser CJ: Increased expression of cyclooxygenase-2 correlates with resistance to radiation in human prostate adenocarcinoma cells. J Urol 177: 1913-1917, 2007.

10. Khor LY, Bae K, Pollack A, Hammond ME, Grignon DJ, Venkatesan VM, Rosenthal SA, Ritter MA, Sandler HM, Hanks GE, et al: COX-2 expression predicts prostate-cancer outcome: Analysis of data from the RTOG 92-02 trial. Lancet Oncol 8: 912-920, 2007.

11. Richardsen E, Uglehus RD, Due J, Busch C and Busund LT: COX-2 is overexpressed in primary prostate cancer with metastatic potential and may predict survival. A comparison study between COX-2, TGF-beta, IL-10 and Ki67. Cancer Epidemiol 34: 316-322, 2010.

12. Ceylan Y, Lekili M, Muezzinoglu T, Nese N and Isisag A: Predictive value of cyclooxygenase- 2 over expression for identifying prostate cancer from benign prostatic hyperplasia in prostate biopsy specimens. Minerva Urol Nefrol 68: 255-262, 2016.

13. Zheng X, Cui XX, Gao Z, Zhao Y, Lin Y, Shih WJ, Huang MT, Liu Y, Rabson A, Reddy B, et al: Atorvastatin and celecoxib in combination inhibits the progression of androgen-dependent $\mathrm{LNCaP}$ xenograft prostate tumors to androgen independence. Cancer Prev Res (Phila) 3: 114-124, 2010.

14. Zheng X, Cui XX, Avila GE, Huang MT, Liu Y, Patel J, Kong AN, Paulino R, Shih WJ, Lin Y, et al: Atorvastatin and celecoxib inhibit prostate PC-3 tumors in immunodeficient mice. Clin Cancer Res 13: 5480-5487, 2007.

15. Chen J, Shen P, Zhang XC, Zhao MD, Zhang XG and Yang L: Efficacy and safety profile of celecoxib for treating advanced cancers: A meta-analysis of 11 randomized clinical trials. Clin Ther 36: 1253-1263, 2014.

16. Patel MI, Subbaramaiah K, Du B, Chang M, Yang P, Newman RA, Cordon-Cardo C, Thaler HT and Dannenberg AJ: Celecoxib inhibits prostate cancer growth: Evidence of a cyclooxygenase2-independent mechanism. Clin Cancer Res 11: 1999-2007, 2005

17. Kashiwagi E, Shiota M, Yokomizo A, Inokuchi J, Uchiumi T and Naito S: EP2 signaling mediates suppressive effects of celecoxib on androgen receptor expression and cell proliferation in prostate cancer. Prostate Cancer Prostatic Dis 17: 10-17, 2014.

18. Pruthi RS, Derksen JE, Moore D, Carson CC, Grigson G, Watkins $\mathrm{C}$ and Wallen E: Phase II trial of celecoxib in prostatespecific antigen recurrent prostate cancer after definitive radiation therapy or radical prostatectomy. Clin Cancer Res 12: 2172-2177, 2006.
19. Murad AS, Down L, Davey Smith G, Donovan JL, Athene Lane J, Hamdy FC, Neal DE and Martin RM: Associations of aspirin, nonsteroidal anti-inflammatory drug and paracetamol use with PSA-detected prostate cancer: Findings from a large, populationbased, case-control study (the ProtecT study). Int J Cancer 128: 1442-1448, 2011

20. Liu X, Plummer SJ, Nock NL, Casey G and Witte JS: Nonsteroidal antiinflammatory drugs and decreased risk of advanced prostate cancer: Modification by lymphotoxin alpha. Am J Epidemiol 164: 984-989, 2006.

21. Dasgupta K, Di Cesar D, Ghosn J, Rajan R, Mahmud S and Rahme E: Association between nonsteroidal anti-inflammatory drugs and prostate cancer occurrence. Cancer J 12: 130-135, 2006.

22. Liu Y, Chen JQ, Xie L, Wang J, Li T, He Y, Gao Y, Qin X and Li S: Effect of aspirin and other non-steroidal anti-inflammatory drugs on prostate cancer incidence and mortality: A systematic review and meta-analysis. BMC Med 12: 55, 2014.

23. Choe KS, Cowan JE, Chan JM, Carroll PR, D'Amico AV and Liauw SL: Aspirin use and the risk of prostate cancer mortality in men treated with prostatectomy or radiotherapy. J Clin Oncol 30: 3540-3544, 2012.

24. Choe KS, Correa D, Jani AB and Liauw SL: The use of anticoagulants improves biochemical control of localized prostate cancer treated with radiotherapy. Cancer 116: 1820-1826, 2010.

25. Jacobs EJ, Newton CC, Stevens VL, Campbell PT, Freedland SJ and Gapstur SM: Daily aspirin use and prostate cancer-specific mortality in a large cohort of men with nonmetastatic prostate cancer. J Clin Oncol 32: 3716-3722, 2014

26. Huang H, Cui XX, Chen S, Goodin S, Liu Y, He Y, Li D, Wang H, Van Doren J, Dipaola RS, et al: Combination of Lipitor and Celebrex inhibits prostate cancer $\mathrm{VCaP}$ cells in vitro and in vivo. Anticancer Res 34: 3357-3363, 2014.

27. Huang H, He Y, Cui XX, Goodin S, Wang H, Du ZY, Li D, Zhang K, Tony Kong AN, DiPaola RS, et al: Potent inhibitory effect of $\delta$-tocopherol on prostate cancer cells cultured in vitro and grown as xenograft tumors in vivo. J Agric Food Chem 62: 10752-10758, 2014

28. Wei X, Zhou D, Wang H, Ding N, Cui XX, Wang H, Verano M, Zhang K, Conney AH,Zheng X, et al: Effects of pyridine analogs of curcumin on growth, apoptosis and NF- $\mathrm{KB}$ activity in prostate cancer PC-3 cells. Anticancer Res 33: 1343-1350, 2013.

29. Ding N, Cui XX, Gao Z, Huang H, Wei X, Du Z, Lin Y, Shih WJ, Rabson $\mathrm{AB}$, Conney $\mathrm{AH}$, et al: A triple combination of atorvastatin, celecoxib and tipifarnib strongly inhibits pancreatic cancer cells and xenograft pancreatic tumors. Int J Oncol 44: 2139-2145, 2014

30. Huang TB, Yan Y, Guo ZF, Zhang XL, Liu H, Geng J, Yao XD and Zheng JH: Aspirin use and the risk of prostate cancer: A meta-analysis of 24 epidemiologic studies. Int Urol Nephrol 46: 1715-1728, 2014.

31. Vane JR and Botting RM: The mechanism of action of aspirin. Thromb Res 110: 255-258, 2003.

32. Yoshimura R, Matsuyama M, Kawahito Y, Takemoto $Y$, Tsuchida K, Kuratsukuri K, Segawa Y, Shinnka T, Sano H and Nakatani T: The effects of cyclooxygenase-2 inhibitors on urological cancer cells. Int J Mol Med 13: 789-793, 2004.

33. Michalik L, Desvergne B and Wahli W: Peroxisome-proliferatoractivated receptors and cancers: Complex stories. Nat Rev Cancer 4: 61-70, 2004.

34. Farnier M and Davignon J: Current and future treatment of hyperlipidemia: The role of statins. Am J Cardiol 82: 3J-10J, 1998.

35. McFarlane SI, Muniyappa R, Francisco R and Sowers JR: Clinical review 145: Pleiotropic effects of statins: lipid reduction and beyond. J Clin Endocrinol Metab 87: 1451-1458, 2002.

36. Goldstein JL and Brown MS: Regulation of the mevalonate pathway. Nature 343: 425-430, 1990.

37. Pruitt K and Der CJ: Ras and Rho regulation of the cell cycle and oncogenesis. Cancer Lett 171: 1-10, 2001.

38. Olivan M, Rigau M, Colás E, Garcia M, Montes M, Sequeiros T, Regis L, Celma A, Planas J, Placer J, et al: Simultaneous treatment with statins and aspirin reduces the risk of prostate cancer detection and tumorigenic properties in prostate cancer cell lines. Biomed Res Int 2015: 762178, 2015.

39. Stark LA, Reid K, Sansom OJ, Din FV, Guichard S, Mayer I, Jodrell DI, Clarke AR and Dunlop MG: Aspirin activates the NF-kappaB signalling pathway and induces apoptosis in intestinal neoplasia in two in vivo models of human colorectal cancer. Carcinogenesis 28: 968-976, 2007. 